\title{
Lack of DNA Damage Induced by Fluoride on Mouse Lymphoma and Human Fibroblast Cells by Single Cell Gel (Comet) Assay
}

\author{
Daniel Araki RIBEIRO \\ Patrícia Lepage ALVES DE LIMA \\ Mariângela Esther Alencar MARQUES \\ Daisy Maria Fávero SALVADORI \\ Center for Genotoxin and Carcinogen Evaluation (TOXICAN), \\ Department of Pathology, Faculty of Medicine of Botucatu, State University of São Paulo, Botucatu, SP, Brazil
}

\begin{abstract}
Fluoride has widely been used in Dentistry because it is a specific and effective caries prophylactic agent. However, excess fluoride may represent a hazard to human health, especially by causing injury on genetic apparatus. Genotoxicity tests constitute an important part of cancer research for risk assessment of potential carcinogens. In this study, the potential DNA damage associated with exposure to fluoride was assessed by the single cell gel (comet) assay in vitro. Mouse lymphoma and human fibroblast cells were exposed to sodium fluoride (NaF) at final concentration ranging from 7 to $100 \mu \mathrm{g} / \mathrm{mL}$ for $3 \mathrm{~h}$ at $37^{\circ} \mathrm{C}$. The results pointed out that $\mathrm{NaF}$ in all tested concentrations did not contribute to DNA damage as depicted by the mean tail moment and tail intensity for both cellular types assessed. These findings are clinically important because they represent a valuable contribution for evaluation of the potential health risk associated with exposure to agents usually used in dental practice.
\end{abstract}

Key Words: comet assay, sodium fluoride, mouse lymphoma cells, human fibroblasts.

\section{INTRODUCTION}

Fluoride intake in low concentrations during tooth development results in the formation of a more caries-resistant enamel structure (1). It has been established that a concentration of $0.7 \mathrm{ppm}$ fluoride reduces caries by $40-49 \%$ in primary teeth and $50-59 \%$ in permanent teeth, with no clinically detectable adverse effects (2). However, some human populations are exposed to high doses of fluoride, mainly in developing countries. In this context, studies focusing on possible genotoxic effect of excess fluoride are contradictory and inconclusive. According to some authors, fluoride does not induce DNA damage (3-6). However, some authors have observed the mutagenic potential of fluoride in Drosophila melanogaster (7) as well as synergistic and antagonist effect with known genotoxins (8).
Over the past decade, the single cell gel (comet) assay in alkaline version has been used as a rapid, simple and reliable biochemical technique for evaluating DNA damage in mammalian cells (9). The basic principle of the single cell gel (comet) assay is the migration of DNA in an agarose matrix under electrophoretic conditions. Viewed under a microscope, a cell has the appearance of a comet, with a head (the nuclear region) and a tail containing DNA fragments or strands migrating in the direction of the anode. This assay is particularly important for investigation of suspected genotoxins in vitro $(10,11)$.

The purpose of this study was to investigate whether sodium fluoride $(\mathrm{NaF})$ can induce DNA breakage in mouse lymphoma and human fibroblast cells by the single cell gel (comet) assay in vitro. The results would contribute to a better understanding of the mechanism of $\mathrm{NaF}$ concerning genotoxicity upon the cell system.

Correspondence: Dr. Daniel Araki Ribeiro, Núcleo de Avaliação Toxicogenética e Cancerígena (TOXICAN), Departamento de Patologia, Faculdade de Medicina de Botucatu, UNESP, Distrito de Rubião Jr. S/N, 18618-000 Botucatu, SP, Brasil. Tel: +55-14-3882-8255. Fax: +5514-3815-2348. e-mail: ak92@hotmail.com 


\section{MATERIAL AND METHODS}

All procedures in this study were approved by and performed in compliance with the Ethics Committee of the Faculty of Medicine of Botucatu, UNESP, Brazil. Cell Culture. L5178Y mouse lymphoma cells were cultivated in suspension in RMPI 1640 glutamax medium (Amersham Life Sciences Inc., Arlington Heights, IL, USA) supplemented with $10 \%$ heatinactivated horse serum and penicillin/streptomycin (Life Technologies, Grand Island, NY, USA) at $100 \mu \mathrm{g} /$ $\mathrm{mL}$ at $37^{\circ} \mathrm{C}$ with $5 \% \mathrm{CO}_{2}$ according to Rothfuss et al. (12). Human fibroblasts were cultivated as described by Stanley et al. (13). Namely, a fragment biopsy was extracted from skin and fibroblasts were seeded into each dish of multiwells (Corning, $10 \mathrm{~cm}$ in diameter) at $37^{\circ} \mathrm{C}$ in a $95 \%$ air $/ 5 \% \mathrm{CO}_{2}$ humidified incubator in Dulbecco's Modified Essential Medium (DMEM; Life Technologies) supplemented with $20 \%$ fetal calf serum and $100 \mathrm{U} / \mathrm{mL}$ penicillin and $100 \mu \mathrm{g} / \mathrm{mL}$ streptomycin (Life Technologies). Cells were cultured for 3 days prior to treatment with the test substance.

NaF Treatment. 1 X $10^{5}$ cells $(\sim 10 \mu \mathrm{L})$ were used in each treatment. Ten microliter of $\mathrm{NaF}$ (SigmaAldrich Corp., St. Louis, MO, USA) were added to the suspension of cells to give a final concentration that ranged from 7-100 $\mu \mathrm{g} / \mathrm{mL}$. These concentrations were defined as described in previous studies $(14,15)$. The same volume was added to control cultures of either negative control (distilled water) or a reference alkylating agent methylmethane sulfonate (MMS) (Sigma-Aldrich Corp.) at $10 \mu \mathrm{g} / \mathrm{mL}$ concentration (positive control). Each substance was tested in at least 3 separate experiments for each individual treatment. After incubation for $3 \mathrm{~h}$ at $37^{\circ} \mathrm{C}$, the cells were centrifuged at $1000 \mathrm{rpm}$ during $5 \mathrm{~min}$ and washed twice with fresh medium and ressuspended with fresh medium.

Single Cell Gel (Comet) Assay. The protocol used for single cell gel (comet) assay for each treatment and controls followed the guidelines recommended by Tice et al (9). Briefly, $10 \mu \mathrm{L}$ of cells $\left(\sim 1 \times 10^{5}\right.$ cells) were added to $120 \mu \mathrm{L}$ of $0.5 \%$ low-melting point agarose at $37^{\circ} \mathrm{C}$, layered onto a pre-coated slide with $1.5 \%$ regular agarose and covered with a coverslip. After brief agarose solidification in refrigerator, the coverslip was removed and the slides were immersed in a lysing solution consisting of $2.5 \mathrm{M}$ sodium chloride, $100 \mathrm{mM}$ ethylenediaminetetraacetic (EDTA), $10 \mathrm{mM}$
Tris- $\mathrm{HCl}$ buffer at $\mathrm{pH} 10,1 \%$ sodium sarcosinate with $1 \%$ Triton X-100 and 10\% dymethylsulfoxide (DMSO) for about $1 \mathrm{~h}$.

Prior to electrophoresis, the slides were left in alkaline buffer containing $0.3 \mathrm{mM} \mathrm{NaOH}$ and $1 \mathrm{mM}$ EDTA $(\mathrm{pH}>13)$ for $20 \mathrm{~min}$ and electrophoresed for another $20 \mathrm{~min}$ at $25 \mathrm{~V}(0.86 \mathrm{~V} / \mathrm{cm})$ and $300 \mathrm{~mA}$. After electrophoresis, the slides were neutralized in $0.4 \mathrm{M}$ Tris- $\mathrm{HCl}(\mathrm{pH} 7.5)$, fixed in absolute ethanol and stored at room temperature until blind analysis in a fluorescence microscope (Olympus; Optical Co. Ltd, Tokyo, Japan) at X400 magnification. To minimize extraneous DNA damage from ambient ultraviolet radiation, all steps were performed with reduced illumination.

DNA Damage. An automated analytical software (Comet Assay 2.2; Perceptive Instruments, Haverhill, UK) was used to determine DNA damage. Two parameters were estimated: tail moment (product of tail DNA/total DNA by the center of gravity) and tail intensity (percentage of DNA in the tail) from 50 cells per treatment.

Cytotoxicity Assay. Cell viability test for mouse lymphoma and human fibroblast cells was performed using Tripan blue staining before treatment (9). Namely, a freshly prepared solution of $10 \mu \mathrm{L}$ Tripan blue $(0.05 \%)$ in distilled water were mixed to $10 \mu \mathrm{L}$ of each cellular suspension during $5 \mathrm{~min}$, spread onto a microscope slide and covered with a coverslip. Non-viable cells were blue-stained. At least 200 cells were counted.

Statistical Methods. Parameters in triplicate from the single cell gel (comet) assay for treated cells versus control cells were compared by one-way ANOVA followed by a post-hoc analysis at 5\% significant level using the SPSS statistical software package, version 1.0 for Windows (SPSS Inc., Chicago, IL, USA).

\section{RESULTS}

The single cell gel (comet) assay was used to measure DNA damage in mouse lymphoma and human fibroblast cells in vitro. DNA strand breaks were represented by the mean tail moment and tail intensity for 50 comets per sample.

In all tested concentrations, $\mathrm{NaF}$ did not induce strand breakage in DNA of either mouse lymphoma cells (Table 1) or human fibroblast cells (Table 2). The mean cell viability was approximately $95 \%$ for both cell types assessed. 


\section{DISCUSSION}

The aim of this study was to evaluate in vitro the $\mathrm{NaF}$-induced genotoxic damage in different cell types using the single cell gel (comet) assay. Mouse lymphoma cells were chosen to investigate fluoride genotoxicity because the mechanism of DNA damage induced in these cells has been well documented. Human fibroblast cells were utilized because they represent ordinary cells. We believe that cell cultures have advantages over animal experimentation because they exclude the complex homeostatic mechanisms that occur in vivo.

It is noteworthy that the alkaline version of the single cell gel (comet) assay used here is sensitive for a wide variety of DNA lesions. Among them are DNA strand breaks, alkali-labile sites including abasic sites and incomplete repair sites. According to the proposed in vitro single cell (gel) comet assay testing guidelines (9), cells should be exposed for 3-6 h. Herein, in this study, NaF was exposed for $3 \mathrm{~h}$. Considering that alkylating agents are expected to be the most potent and abundant chemical DNA-damaging agent in our environment (16), MMS was used for alkylation damage, serving as a positive control.

Fluoride is well known as a specific and effective caries prophylactic agent and its systemic or local application has therefore been recommended widely over the past decades. However, excessive concentrations may cause extensive damage to biological systems. It has been established that therapeutic exposure to xenobiotics may result in their covalent binding to

Table 1. Mean $( \pm \mathrm{SD})$ of DNA damage (tail moment and tail intensity) in mouse lymphoma cells exposed to $\mathrm{NaF}$.

\begin{tabular}{lcc}
\hline $\mathrm{NaF}(\mu \mathrm{g} / \mathrm{mL})$ & \multicolumn{2}{c}{ DNA damage $^{1}$} \\
\cline { 2 - 3 } & Tail moment & Tail intensity \\
\hline 0 & $0.25 \pm 0.19$ & $2.05 \pm 1.89$ \\
7 & $0.21 \pm 0.11$ & $1.90 \pm 1.25$ \\
28 & $0.52 \pm 0.15$ & $2.02 \pm 0.47$ \\
56 & $0.24 \pm 0.12$ & $2.12 \pm 1.13$ \\
100 & $0.22 \pm 0.10$ & $1.85 \pm 0.16$ \\
$\mathrm{MMS}^{2}$ & $3.87 \pm 1.40^{*}$ & $17.00 \pm 5.29^{*}$ \\
\hline
\end{tabular}

${ }^{1}$ Data from three independent experiments. ${ }^{2}$ Methylmethasulfonate at $10 \mu \mathrm{g} / \mathrm{mL}$ concentration. * indicates statistically significant difference at $\mathrm{p}<0.05$.
DNA, which may lead to genetic damage and could be an initial event in the process of chemical carcinogenesis (17). NaF, the first and still most recommended fluoride compound for fluoridation of drinking water, was able to induce morphological and neoplastic transformation of Syrian hamster embryo cells (18), as well as to increase chromosomal aberrations in Chinese hamster ovary cells (19). Furthermore, studies have shown that, although it is a non-oxidant ion, $\mathrm{NaF}$ caused oxidative stress indirectly leading to DNA breakage (19). The findings of the present study clearly demonstrated that $\mathrm{NaF}$ in all tested concentrations did not cause damage to DNA of either mouse lymphoma or human fibroblast cells. It is assumed that these negative results are because fluoride is not capable of forming adducts on the bases of DNA or those that intercalate into DNA secondary structure. These results are consistent with those of previous studies (3-6,15). An earlier study conducted by our research group revealed that $\mathrm{NaF}$ did not induce DNA damage in oral mucosa cells in vitro as well (11). On the other hand, it has been shown that $\mathrm{NaF}$ inhibited both protein and DNA synthesis in cultures of mammalian cells (20). It may be speculated that this inhibition of DNA synthesis is a secondary effect on DNA because there is no apparent mechanism by which the reported genotoxic effects can be induced by direct interaction of fluoride with DNA.

According to the proposed in vitro single cell gel (comet) assay testing guidelines (9), highly damaged DNA may correspond to dead cells; the latter were excluded from the analysis because they could reflect

Table 2. Mean $( \pm \mathrm{SD})$ of DNA damage (tail moment and tail intensity) in human fibroblast cells exposed to $\mathrm{NaF}$.

\begin{tabular}{|c|c|c|}
\hline \multirow[t]{2}{*}{$\mathrm{NaF}(\mu \mathrm{g} / \mathrm{mL})$} & \multicolumn{2}{|c|}{ DNA damage $^{1}$} \\
\hline & Tail moment & Tail intensity \\
\hline 0 & $0.46 \pm 0.13$ & $3.69 \pm 1.66$ \\
\hline 7 & $0.53 \pm 0.17$ & $6.77 \pm 3.27$ \\
\hline 28 & $0.36 \pm 0.15$ & $5.40 \pm 1.22$ \\
\hline 56 & $0.20 \pm 0.15$ & $2.59 \pm 1.39$ \\
\hline 100 & $0.44 \pm 0.14$ & $5.36 \pm 1.90$ \\
\hline $\mathrm{MMS}^{2}$ & $3.50 \pm 1.98^{*}$ & $22.59 \pm 6.48^{*}$ \\
\hline
\end{tabular}


possible cytotoxicity. Therefore, it is recommends that cellular viability is assessed concurrently with the single cell gel (comet) assay (18). In the present study, mouse lymphoma and human fibroblast cells were tested for cytotoxicity by trypan blue exclusion, and it was noticed that over $95 \%$ of cells excluded trypan constantly.

In conclusion, the results of this study indicated that $\mathrm{NaF}$ is not a genotoxin. Since genotoxicity tests constitute an important part of cancer research for risk assessment of potential carcinogens, the findings hereby reported represent a valuable contribution for evaluation of the potential health risk associated with agents usually used in dental practice.

\section{RESUMO}

O flúor tem sido amplamente usado na Odontologia, pois é um agente profilático efetivo e específico contra a cárie dentária. Entretanto, o flúor em excesso pode representar perigos à saúde humana, especialmente por causar agressão ao material genético. Testes de genotoxicidade constituem uma parte importante da pesquisa do câncer para a avaliação de risco de possíveis carcinógenos. Neste estudo, danos ao DNA associados à exposição ao flúor foram avaliados pelo teste de células individualizadas em gel de agarose (teste do cometa) in vitro. Células de linfoma murino e fibroblastos humanos foram expostas ao fluoreto de sódio (NaF) nas concentrações finais de 7 a $100 \mu \mathrm{g} /$ $\mathrm{mL}$ durante $3 \mathrm{~h}$ a $37^{\circ} \mathrm{C}$. Os resultados mostraram que o $\mathrm{NaF}$ não contribuiu para os danos ao DNA em ambos os tipos celulares estudados e em todas as concentrações testadas, conforme demonstrado pelas médias do momento da cauda e intensidade da cauda dos cometas. Estes achados são clinicamente importantes, uma vez que representam uma importante contribuição para a avaliação do risco potencial à saúde associada à exposição a agentes geralmente empregados na prática odontológica.

\section{ACKNOWLEDGEMENTS}

This work was supported by Brazilian research funding agencies (CNPq and FAPESP) and TOXICAN (Núcleo de Avaliação Toxicogenética e Cancerígena).

\section{REFERENCES}

1. Denbesten PK, Thariani H. Biological mechanisms of fluorosis and level and timing of systemic exposure to fluoride with respect to fluorosis. J Dent Res 1992;71:1238-1243.

2. World Health Organization (WHO). Available from URL: http://home.iae.nl/users/lightnet/health/fluoride.htm; 1994.

3. IARC (International Agency for Research on Cancer) Monographs. Inorganic fluorides used in drinking-water and dental preparations. IARC Monogr Eval Carcinog Risk Chem Hum 1982;27:237-303.

4. Kleinsasser NH, Weissacher H, Wallner BC, Kastenbauer ER,
Harreus UA. Cytotoxicity and genotoxicity of fluorides in human mucosa and lymphocytes. Laryngohinootologie 2001;80:187-190.

5. Li YM, Zhang W, Noblitt TW, Dunipace AJ, Stookey GK. Genotoxic evaluation of chronic fluoride exposition: sisterchromatid exchange study. Mutat Res 1989;227:159-165.

6. Slamenova D, Gabelova A, Ruppova K. Cytotoxicity and genotoxicity testing of sodium fluoride on Chinese hamster V79 cells and human EUE cells. Mutation Res 1992;16:109115 .

7. Gerdes RA. The influence of atmospheric hydrogen fluoride on the frequency of sex-linked lethal and sterility in Drosophila melanogaster. Fluoride 1971;4:25-29.

8. Monsour PA, Kruger BJ, Smid JR. Effects of a single intravenous dose of sodium fluoride on plasma electrolytes and metabolites in rats, rabbits and cockerels. J Dent Res 1985;64:1281-1285.

9. Tice RR, Agurell E, Anderson D, Burlinson B, Hartmann A, Kobayashi H, Miyamae Y, Rojas E, Ryu JC, Sasaki YF. Single cell gel/comet assay: guidelines for in vitro and in vivo genetic toxicology testing. Envirom Mol Mutag 2000;35:206-221.

10. Ribeiro DA, Marques MEA, Salvadori DMF. Lack of genotoxicity of formocresol, paramonochlorophenol, and calcium hydroxide on mammalian cells by comet assay. J Endod 2004;30:593-596.

11. Ribeiro DA, Salvadori DMF, Assis GF, Marques MEA. Does fluoride cause DNA damage? An evaluation in vitro using rat oral mucosa cells. Braz J Oral Sci 2003;2:268-271.

12. Rothfuss A, Merck, O. Radermacher P, Speit G. Evaluation of mutagenic effects of hyperbaric oxygen (HBO) in vitro II. Induction of oxidative DNA damage and mutations in the mouse lymphoma assay. Mutat Res 2000;471:87-94.

13. Stanley AC, Park HY, Phillips TJ, Russakovsky V, Menzolan JO. Reduced growth of dermal fibroblasts from chronic venous ulcers can be stimulated with growth factors. J Vasc Surg 1997;26:994-1001.

14. Aardema MJ, Gibson DP, LeBoeuf RA. Sodium fluorideinduced chromosome aberrations in different stages of the cell cycle: a proposed mechanism. Mutat Res 1989;223:191203.

15. Tong CC, McQueen CA, VedBrat S, Williams GM. The lack of genotoxicity of sodium fluoride in a battery of cellular tests. Cell Biol Toxicol 1988;4:173-186.

16. Kuehl DW, Serrano S, Naumann S. Identification of potentially mutagenic contaminants in the aquatic environmental by liquid chromatographic-thermospray mass spectrometric characterization of in vitro DNA adducts. J Chromatogr A 1994;684:1113-1119.

17. Fairbain DW, Olive PL, O'Neill KL. The comet assay: a comprehensive review. Mutat Res 1995;339:37-59.

18. Jones CA, Callaham MF, Huberman E. Sodium fluoride promotes morphological transformation of Syrian hamster cells. Carcinogenesis 1988;9:2279-2284.

19. Anuradha CD, Kanno S, Hirano S. Oxidative damage to mitochondria is a preliminary step to caspase-3 activation in fluoride-induced apoptosis in HL-60 cells. Free Rad Biol Med 2000;31:367-373.

20. Holland HI. Fluoride inhibition of protein and DNA synthesis in cell in vitro. Acta Pharmacol Toxicol 1979;45:96-101.

Accepted August 18, 2004 